\title{
The Causes and Effects of Leaks in International Negotiations* ${ }^{*}$
}

\author{
Matthew Castle甲
}

Krzysztof J. Pel用

\begin{abstract}
International negotiations are founded on secrecy. Yet unauthorized leaks of negotiating documents have grown common. What are the incentives behind leaks, and what are their effects on bargaining between states? Specifically, are leaks offensive or defensive: are they intended to spur parties to make more ambitious commitments, or are they more often intended to claw back commitments made? We examine these questions in the context of trade negotiations, the recurring form of which affords us rare empirical traction on an otherwise elusive issue. We assemble the first dataset of its kind, covering 120 discrete leaks from 2006 to 2015 . We find that leaks are indeed rising in number. Leaks are clustered around novel legal provisions, and appear to be disproportionately defensive: they serve those actors intent on limiting commitments made. The European Union appears responsible for the majority of leaks occurring worldwide. Using party manifesto data to track changing ideological positions within the EU, we find that the occurrence of leaks correlates with opposition to economic liberalization within the average EU political party. Moreover, leaks appear effective in shifting public debate. We examine trade officials' internal communications and media coverage in the wake of a specific leak of negotiations between Canada and the EU. A given negotiating text attracts more negative coverage when it is leaked than when the same text is officially released. In sum, political actors leak information strategically to mobilize domestic audiences towards their preferred negotiating outcome.
\end{abstract}

*Authors' note: We thank participants at APSA 2016 Annual Meeting and seminars at McGill University for most helpful comments, and Brianna Brown and Sean Nossek for excellent research assistance.

${ }^{\dagger}$ Lecturer, School of History, Philosophy, Political Science and International Relations, Victoria University of Wellington, matthew.castle@mail.mcgill.ca

${ }^{\ddagger}$ Associate Professor, Department of Political Science, McGill University, kj.pelc@mcgill.ca 


\section{Introduction}

Much of politics is designed to be hidden from public view. Citing commercial interests, national security, or diplomatic practice, governments purposefully keep a significant part of their activity from their own audiences. But the walls often prove porous: private information gets leaked. This may be especially true during times of political upheaval and discord.

The administration of US President Trump, for instance, has been plagued by leaks. Investigations into leakers have reportedly tripled compared to the prior administration ${ }^{1}$ In September 2017, National Security Advisor H.R. McMaster proposed a government-wide crackdown on unauthorised disclosures not only of classified information, but also of controlled unclassified information. Tellingly, this anti-leak memo was itself leaked to the press $2^{2}$ Leaks from the Trump administration reveal a divided White House. As one seasoned Republican strategist suggests, "Trump's White House is not leaky because of a few bad apples. The No. 1 reason why it leaks is because his team lacks unity ... many of the leaks are about the very staff infighting that is causing the leaks.' 3

The international setting is proving just as porous. In international negotiations, especially, leaks of draft texts, chapters, or negotiating positions have become increasingly salient. What are the motivations for these targeted leaks, and what effect do they have on bargaining outcomes? Leaks can have profound effects on bargaining: a single leak in the TTIP negotiations is largely to blame for having turned public opinion against the deal. At a time when global integration is increasingly politicized, what can a better understanding of leaks reveal about the politics of international negotiations? The answer, we argue, shares much in common with explanations behind the White House leaks.

Far from being independent, one-off events, our claim is that leaks during international negotiations are strategic, and that this makes them analytically tractable. We begin by striking a distinction between offensive and defensive leaks. Offensive leaks occur when a party leaks information to get the opposing negotiating party to concede to more, as when bringing to light an opposing party's intransigence. Defensive leaks take place when the leaked information is meant

\footnotetext{
${ }^{1}$ Charlie Savage and Eileen Sullivan, "Leak Investigations Triple Under Trump, Sessions Says", New York Times (August 4, 2017). https://www.nytimes.com/2017/08/04/us/politics/ jeff-sessions-trump-leaks-attorney-general.html.

${ }^{2}$ Matthew Yglesias, "The Trump administration's big new anti-leak memo leaked last night", Vox (September 14, 2017). https://www.vox.com/policy-and-politics/2017/9/14/16305384/mcmaster-memo-leaks.

${ }^{3}$ Alex Conant, "Why Trump's White House Won?t Stop Leaking", Politico Magazine (July 27, 2017). https: //www.politico.com/magazine/story/2017/07/27/anthony-scaramucci-leaks-215429
} 
to hinder negotiations, as when revealing a position or concession that will prove unpopular. Both types of leaks aim to mobilize domestic audiences in order to place political pressure on negotiators. Offensive leaks seek to spur; defensive leaks seek to spoil. In both cases, they are a means for dissatisfied individuals to bring the outcome of negotiations closer to their own ideal by mobilizing a sympathetic audience, either foreign or domestic.

We use these insights to try and predict the occurrence of leaks in the empirical setting that has witnessed the greatest number of discrete leaks in recent years: international trade negotiations. No major trade accord has been negotiated without its share of leaks, though there is significant variation in the number and extent of those leaks by agreement. We collect a comprehensive record of all the leaks of documents in trade negotiations over the last decade, from 2006 to 2015, amounting to 120 discrete cases of leaked documents. Because trade negotiations deal with recurring issues, these data offer us unprecedented insight into the motives behind, and the effects of, leaks in bargaining between states.

The results are striking. First, the data confirm that the number of leaks is indeed increasing over time during the last decade. Secondly, from descriptives of the leaked documents alone, we find that the European Union appears responsible for the majority of leaks occurring worldwide. And the frequency of those leaks is also increasing, even accounting for the number of EU trade negotiations. This suspicion is consistent with widespread beliefs about how the structure of the EU and its emphasis on transparency within the negotiating process make it especially prone to leaks 4

We further test this belief by turning to party manifesto data. The occurrence of leaks attributable to the EU appears highly correlated with opposition to economic liberalization within the average EU political party: more left-leaning positions among European parties make leaks significantly more likely. We also find that as the divide between Right and Left increases, so does the incidence of leaks. As in the domestic setting, when European politics are more polarized, leaks in international negotiations grow more common.

We also derive expectations over the content of leaks. Most leaks are targeted: they do not contain an entire agreement, but some small portion of it. What explains which parts of

\footnotetext{
${ }^{4}$ The EU's emphasis on transparency was articulated in the 14 October, 2015 release of the European Commission's Trade for All strategy, the second pillar of which is transparency in trade negotiations. This policy responded to the increasing politicization of trade within the EU (?).
} 
negotiated agreements get leaked? Reasoning through the incentives underlying leaks, we argue that if leaks are strategic denouncements, they should target those areas where they will be most effective in shifting debate. As a result, we expect to see more leaks in the "unsettled" areas of the international trade and investment regime, in which past agreements have yet to establish clear expectations about how issues will be regulated.

Do leaks work? We address this question by examining the fallout from one specific highprofile leak. The negotiating text of the Canada-EU Comprehensive Economic and Trade Agreement (CETA) was leaked in August 2014, just one month prior to being officially released. Canadian governmental email correspondence reveals trade officials correctly anticipated domestic political mobilization against CETA as a result of the leak. Moreover, we find that news coverage of the leak was significantly more negative than the coverage of the official release, despite the fact that the text at issue was the same document. These findings suggest leaks can damage governments' efforts to positively frame, and therefore to domestically ratify, international trade agreements.

The remainder of the paper proceeds as follows. The next section develops a theory of leaks - what are the incentives to leak in international negotiations, and what are their effects? We then rely on descriptive statistics to provide the first comprehensive overview of leaks in trade. Next, we use regression analysis to test the link between the occurrence of leaks and EU politics. We then show that leaks are more likely in "unsettled" areas of the international trade regime. Finally, we examine the fallout from a specific leak, to illustrates how leaks have the potential to mobilize targeted groups and affect public debate on trade agreements. We conclude by considering leaks in international negotiations from a normative perspective. Because leaks are targeted, in that they expose some parts of an negotiated agreement but not others, they may increase the odds of mobilization against an agreement that could, in aggregate, benefit the median voter. In this way, leaks do increase transparency of the negotiating process, but they may also end up blocking socially beneficial reforms. 


\section{A Theory of Leaks in International Negotiations}

\subsection{The Role of Secrecy}

International negotiations are founded on secrecy $5^{5}$ Parties keep their positions from one another, and jealously guard the offers and demands made during negotiations from their respective domestic audiences until a final outcome is reached 6 Most plainly, each party in a negotiation stands to gain if it can keep its allowable set of bargaining outcomes private, so that it may appear more intransigent than it is, and extract greater concessions from the opposing side. But secrecy does not only help one party at the expense of the other; it may also increase the odds of a deal being reached.

Of the welfare-enhancing reasons for secrecy in negotiation, issue linkage may be the most common $\sqrt{7}$ Governments rarely negotiate a single issue on a one-dimensional spectrum, like a buyer and a seller bargaining over the price of a house. Most often, a number of issues are linked together, such that concessions that matter to one side can be exchanged against different concessions that matter to the other. Governments may agree to give in on one issue, if they can secure some sizeable advantage in another. In this way, the odds of achieving agreement increase when many issues are combined 8 But if each concession is made known as soon as it is offered, domestic interest groups will mobilize against the deal before it can be proven to be welfare enhancing in aggregate 9 For this reason, the default design of treaty negotiations is to maintain secrecy until a final agreement is reached, and then to seek ratification through an up-or-down vote 10 This design reflects the notion that most international commitments, from trade agreements to climate accords, seek to benefit the country as a whole, but they also create domestic winners and losers in the process. Import-competing industries usually stand to lose from liberalizing agreements, but their decision to mobilize against an agreement is spurred by precise concessions, such as e.g. the reduction of a rule-of-origin requirement on car imports from $60 \%$ regional content to $45 \% 11$ If the winning and

\footnotetext{
${ }^{5} ?, 83$.

${ }^{6} ?, 215$.

${ }^{7}$ ?. In a classic example, institutionalized linkages between agricultural and industrial issues are thought to have encouraged domestically challenging agricultural liberalization in both Japan and Europe (?).

${ }^{8} ? ? ?$.

${ }^{9} ?, 785-86$.

${ }^{10}$ See Meunier's discussion of the EU's difficulty of negotiating under conditions of transparency: ?, 95. Also, ?, 135.

${ }^{11}$ This was one of the more contentious concessions within the TPP negotiations.
} 
losing stakes are precisely identified from the start, those on the losing end will mobilize to block an agreement before the overall beneficial reform has a chance to pass ${ }^{12}$

As is well known, negotiators of international agreements spend as much time negotiating with their domestic constituencies as with their foreign counterparts 13 Secrecy also plays a key function in this two-level aspect of bargaining. Since any bargaining outcome must be satisfactory not only to the executives of each country but also to the domestic ratifying audience, negotiators must clear bargaining room for themselves on both the domestic and the international side. They do this by playing one level against the other. Once a deal is completed, negotiators from both sides routinely return home and declare that they have obtained a favorable deal, in an attempt to secure ratification. This process becomes impossible if the offers made during negotiations are made known to the other level ${ }^{14}$ Secrecy can thus increase the allowable set of outcomes for each side, magnifying the odds of any agreement being reached.

For these reasons, governments have always sought to hold negotiations in secret, and diplomacy in general is traditionally a closed realm $\sqrt{15}$ Yet the walls often prove porous. In recent years, especially, salient leaks have come to dominate the headlines ${ }^{16}$ Helped by increasingly sophisticated means of anonymously transferring large amounts of information, individuals have leaked restricted negotiating documents, sometimes containing thousands of pages, to the media. What is the purpose of these leaks? And might a better understanding of the incentives underlying leaks allow us to predict their occurrence?

\subsection{Offensive vs. Defensive Leaks}

We begin by distinguishing between leaks according to their purpose. Leaks aim either to spur or to spoil. They either seek to pressure a recalcitrant party to concede more, or they seek to claw back commitments made by a party seen as overzealous. Both types of leaks are denouncements aimed at domestic audiences, and both seek to mobilize.

\footnotetext{
${ }^{12}$ For analogous reasons, ? warned that the increasing legalization of international relations, by detailing who stood to lose how much from agreements, would lead to mobilization against welfare-enhancing agreements by import-competing groups, who tended to represent more concentrated interests.

${ }^{13} ?$.

$14 ? ? ?$.

${ }^{15}$ The need for secrecy and demands for transparency are in tension in many issue-areas in international relations. See for instance ?????.

16 ?.
} 
In the first case, offensive leaks aim to bring to light how a recalcitrant party's position clashes with that of domestic groups. They can show how an opposing party is thwarting the negotiations, and can thereby mobilize global audiences. Yet in most cases, governments are likely to be most swayed by their own audiences, and leaks are most likely to take this into account by targeting those domestic audiences. Offensive leaks thus seek to expose a party's intransigence, to build pressure on it to concede more.

As an example, in December 2009, world leaders met in Copenhagen to make commitments on reducing emissions to combat climate change. A leak of the countries' positions was sent to the German magazine Der Spiegel. The leak revealed that China was the main party holding up the negotiation: on the last day of the talks, it had refused to commit to the 50 percent reduction of emissions by 2050 (with 1990 as the benchmark year) which had been the stated ambition of the summit. The leak also singled out India for its intransigence. European leaders were shown exhorting both developing countries to agree to a binding commitment of any sort, without success. A representative headline read, "How China and India Sabotaged the UN Climate Summit" 17 The author of the leak succeeded in denouncing China and India's unwillingness to commit, compared to European countries. The episode was seen as an embarrassment to both China and India. It is plausible that this single leak had an effect on global climate negotiations when the same leaders met again over the following years, culminating in the successful COP21 meeting in Paris in 2015.

What makes this an offensive leak for the purpose of our theory is that its aim was to spur other parties to make further concessions. In this case, the denouncement of the refusal by China and India to make any binding commitment increased pressure on these countries to make a commitment during subsequent talks. Although one can imagine a disgruntled Chinese negotiator leaking the parties' positions owing to her dissatisfaction with her own government's position, it appears more plausible that the source of the leak came from the side pushing for further commitments. The leak's publication in a German news outlet seems consistent with this view.

Contrast this with defensive leaks. Here, the objective is the opposite. Defensive leaks bring to light provisions that are perceived as excessive, in order to rein these in. These also seek

\footnotetext{
${ }^{17}$ Der Spiegel, Tobias Rapp, Christian Schwgerl and Gerald Traufetter. 05/05/2010. http://www.spiegel.de/ international/world/the-copenhagen-protocol-how-china-and-india-sabotaged-the-un-climate-summit-a-692861-druck . html.
} 
to denounce, but they do so in order to spoil negotiations. The assumption underlying defensive leaks is that the specific provision being leaked will be sufficiently objectionable to audiences that it will lead to mobilization against that provision, or the treaty as a whole.

Keeping to the very same negotiations for consistency, consider the 2009 leak of the "Danish text." This draft agreement prepared by developed countries months earlier was leaked at the very start of the Copenhagen climate summit. To the dismay of developing countries, it unveiled an attempt to force developing countries to agree to specific emission cuts and measures that were not part of the original UN agreement; called for international verification of emissions (something developing countries like China had objected to under sovereignty concerns); and made adjustment funds for developing countries dependent on a number of climate actions 18 Looking back on the summit several months later, some participants, especially developing country negotiators, faulted the leaked information for having "destroyed Copenhagen from day one."19 If this is to be believed, then the defensive leak should be seen as successful, having spoiled negotiations of an agreement that developing countries judged overly lopsided.

Whomever they target, both offensive and defensive leaks are based on the perception by leakers of a gap between the position expressed in a leaked document and the ideal point of a particular domestic audience. The defensive leak aimed to mobilize interest groups sympathetic to developing country interests, and spoil the alternative deal proposed by developed countries. Later, the offensive leak aimed to mobilize pro-climate regulation constituencies, in an attempt to spur further concessions by developing countries. These two leaks of the same negotiations neatly demonstrate how leaks can be used strategically by opposing interests in a negotiation, to both spoil and spur the aspects of the negotiations they care about.

It is also a testament to the power of agenda setting that domestic actors seek to exert influence over the agreement prior to the stage of ratification 20 Governments use private nego-

\footnotetext{
18 "Copenhagen climate summit in disarray after 'Danish text' leak. The Guardian. December 8, 2009. https:// Www. theguardian.com/environment/2009/dec/08/copenhagen-climate-summit-disarray-danish-text, Last accessed July 13th, 2018.

19 "Copenhagen destroyed by Danish draft leak, says India's environment minister." The Guardian. April 12 , 2019. https://www.theguardian.com/environment/2010/apr/12/copenhagen-destroyed-danish-draft-leak Note that the "Danish text" also hinted at the abandonment of the 1995 Kyoto Protocol, which bound industrialized countries, while demanding little of developing countries. Insofar as this would represent a step back for developing countries, the leak would then acquire an offensive aspect. However, the big takeaway from the leak, and its intended goal, appear to have been to shine a light on the demands made on developing countries, rather than a potential backtracking on the part of developed countries.

${ }^{20} ?$.
} 
tiations to craft a set of concessions that satisfies just enough domestic constituencies to secure ratification. Political actors who fear they will be left out of the deal-be it legislators, interest groups, or non-governmental organizations - have every incentive to affect the agreement's content before it reaches the ratification stage. Going back to the concept of two-level games, there is a range of allowable outcomes that can satisfy the demands of foreign negotiators, and still pass muster domestically. Both defensive and offensive leaks aim to modify the content of an agreement that the leaker perceives will be nonetheless ratifiable.

In sum, the greater the distance between negotiation documents and the ideal point of domestic audiences, the greater the potential for mobilization, and thus the greater the odds of a leak. An individual becomes more likely to leak if the expected subsequent mobilization coincides with that individual's policy preference. In other words, insofar as leaks are strategic, a disgruntled individual would not leak unless the expected outcome is mobilization viewed as favorable by the leaker - either spurring or spoiling the agreement.

Whether they occur in the domestic realm, in the EU system, or at the international level, leaks are designed to secure some political advantage for the leaker ${ }^{21}$ As in the domestic context, such strategic behavior is more likely when political divisions are sharper. Critical scholars may tend to view leaks primarily as opportunities for concerned individuals to act as whistleblowers ${ }^{22}$ a view sustained by coverage of high-profile leaks and leakers such as Edward Snowden and Chelsea Manning ${ }^{23}$ Yet a historical perspective also suggests that “...contrary to public perceptions, leaking is only seldom the province of the dissident."24 In fact, while one may argue over the relative proportion of sanctioned versus unsanctioned leaks, governments routinely plant leaks ${ }^{25}$ According to ?, the Federal US government tolerates a certain amount of illegal leaking, because of overlapping interests in government agencies - for one, these true leaks create the ambiguity required to disguise planted leaks, or 'pleaks' ${ }^{26}$ We follow the distinction made by ?, and identify leaks as the release of any type of information, and restrict whistleblowing to revelations of abuse ${ }^{27}$ Specifically, we identify leaks as formally unauthorized releases of information.

\footnotetext{
${ }^{21} ?, 2, ?, 23, ? ?$.

$22 ?$.

${ }^{23}$ See ? for a historical perspective on this category of leaks.

24?: 35

${ }^{25} ?$.

${ }^{26}$ ?. Others suggest the government is more tightly constrained in its ability to punish leaks: ?.

${ }^{27}$ See also ?, 3 .
} 
While an important focus of past research has been on the legality of the act of leaking and on the enforcement of leaking laws ${ }^{28}$ we turn our attention instead to the political incentives created by leaks' ability to mobilize domestic groups. We then extend this focus to the international realm by discussing how leaks, through their mobilizing capacity, may shape the outcome of ongoing international negotiations. We distinguish leaks based not on the identity of the leaker, but on the political effect of the leak: whom does the leaker intend to mobilize, and to what end? Later, we seek to demonstrate how these ends are achieved: when we compare the coverage of leaked texts with the official unveiling of the same text, we find that the sentiment expressed in post-leak coverage is significantly more negative than following official releases of the same texts. We also trace this to the type of sources cited in each case: as we show, the media coverage of leaks draws more frequently on sources critical of the agreement.

\section{The Record of Leaks in Trade Negotiations}

To better understand the causes and effects of leaks in international negotiations, we consider leaks in one specific domain, that of international trade negotiations. In recent years, the realm of trade and investment treaties has become the most leak-prone area in global governance. Furthermore, trade negotiations, as compared with, e.g. security agreements, deal with a consistent set of issues, making them especially tractable across space and time.

Our central contention is that most, if not all, leaks in the realm of trade negotiations should be of the defensive type. This is for two reasons. First, a tenet of trade theory holds that the main winners from liberalization, consumers, do not mobilize for lower prices, whereas the concentrated import-competing interests that stand to lose from liberalization do. Since the aim of leaks is to mobilize, leaks are more likely to be directed at groups opposed to the agreement than those that favor it: simply put, the opponents of liberalization are better able to mobilize ${ }^{29}$ The distributional effects of trade liberalization might thus explain why trade negotiations are prone to leaks, and why they might be more likely to be defensive in character. But these distributional effects are constant, and so poorly explain an increase in leaks over time. What accounts for this shift, we argue, is a more recent change in the nature of trade negotiations.

\footnotetext{
${ }^{28}$ ????.

${ }^{29}$ This is a common assumption among trade scholars. See e.g. ?.
} 
Traditionally, liberalization has consisted of cutting tariffs, but as these have reached historic lows, liberalization has turned to reducing regulatory discrimination, or regulation that correlates with domestic advantage. This leads to far more contentious treaties, running up as it does against regulatory regimes, an area traditionally falling under sovereign control ??. Trade agreements that promise deep integration have become a complicated exercise in telling apart legitimate regulation that responds to domestic social demands from arbitrary or protectionist regulation which primarily aims to favor domestic industry. The shift towards these "behind-the-border" provisions has created incentives to leak during trade negotiations, as a number of groups created around environmental, health, and safety concerns have risen to push back against further liberalization. Though behind-the-border provisions are increasingly laden with various exceptions seeking to preserve governments' right to regulate - itself a consequence of the pushback 30 - there is little doubt that provisions covering health and safety measures and technical barriers to trade, in aggregate, limit a country's ability to govern over traditionally sovereign areas. This argument fits with well-known accounts of normative contestation. The emergence of new norms in politics invariably runs up against other, established norms. It is in this stage of a norm's "life cycle", prior to what ? calls the "norm cascade," that we expect norms to be most actively contested 31

To illustrate, consider the leak of documents pertaining to TTIP negotiations between the EU and the US in March 2014. While most leaks during negotiations remain anonymous, here is a rare case where the origin is known: a German Green Party Member of the European Parliament (MEP), Sven Giegold, openly admitted to leaking an 18-page document containing guidelines for the EU Council of Ministers in negotiations with the United States. In justifying his breach, the MEP declared: "For me, protection of democracy carries a greater weight than the Commission's interest in undisturbed and secret back-room negotiations." 32 Further, he explained, "a transatlantic trade agreement could wall in our democratic sphere of influence at its heart. For that reason, I decided to publish the confidential mandate."33

The incentive behind the leak is plain. An official with access to confidential documents, member of a party that prioritized "democracy's means for social and environmental management

${ }^{32}$ Green party leaks confidential TTIP paper, Mar 11, 2014, EurActiv.com, http://www.euractiv.com/section/ trade-society/news/green-party-leaks-confidential-ttip-paper/

so ibid.
} 
of the internal market' 34 more than the average European party, sought to bring to light TTIP's content, especially as it concerned the rights the agreement granted firms to challenge governments through investor-state arbitration. His aim was to mobilize domestic pushback among European, and especially German audiences. In this respect, the move was largely successful: the leak coincided with widespread European backlash against TTIP. This single leak marked the beginning of the EU's backtracking on large trade agreements, and on investment provisions in particular.

The Giegold leak constitutes a quintessential defensive leak: its intent to spoil is known. And trade theory suggests that most leaks in trade should have this defensive character. But it is worth asking, what does an offensive leak in trade look like? Recent US political developments have made this easier to imagine. At time of writing, a truism of US trade politics appears reversed: the current US President is more protectionist than legislators of his own party and their constituents, who have been historically favorable to trade agreements 35 Imagine that in this context, the US renegotiates an existing trade agreement "downwards," say by introducing a five-year sunset clause at the President's behest, as has been put forth in the renegotiations of the North American Free Trade Agreement (NAFTA). Had this sunset clause proposal not been made public from the start, Republican legislators might have had a strong incentive to leak it, in an attempt to activate their own relatively more pro-trade constituency, and denounce such an agreement as toothless, and not worth signing. This would constitute an offensive trade leak: it would seek a more ambitious agreement, binding signatories beyond five years ${ }^{36}$ Next, we take a closer look at the data.

\subsection{The Data}

To examine the causes and effects of leaks in trade, we build a dataset of all leaks that occurred between 2006 and 2015, inclusively. To do so, we relied on two news sources dedicated to the dissemination of information about trade negotiations: InsideUSTrade and bilaterals.org. To enter the dataset, a leak must have yielded a document. Some research suggests that oral leaks remain

${ }^{35}$ This runs against the conventional wisdom according to which the House is more protectionist than the Senate, which is more protectionist than the executive. See, e.g. ?.

${ }^{36}$ One interesting implication of the way the traditional left-right divide on trade issues appears to have weakened in recent years is that offensive leaks could become more likely. If right-of-center parties adopt a populist attitude that spurns binding international commitments (?), and trade agreements get diluted as a result, disgruntled mainstream pro-trade legislators could seek to mobilize pro-trade constituencies in favor of deeper agreements by leaking negotiating texts. We thank an anonymous referee for suggesting this possibility.
} 
prevalent despite the rise of 'megaleaks' 37 but we purposefully leave aside leaked "comments" by insiders, as these raise a number of coding issues 38 Similarly, the event had to be explicitly identified as a "leak" or "leaked" document. It had to be, in other words, formally unauthorized by the negotiating governments. We identified a total of 120 distinct leaks of trade agreements from 2006 to 2015. For each of these, we collected data on the relevant negotiations, the date of the leak, its volume in terms of pages of text, the chapter of the trade agreement it covers, and the amount of media coverage it generated. We also coded leaks as either 'offensive' or 'defensive'.

First, we used this comprehensive record of leaks to check whether the frequency of leaks is actually rising. The answer appears to be yes. Figure ?? illustrates this trend, showing the number of leaks in every quarter as well as a trend line for the relative frequency of leaks. Whatever its proximate cause, we can thus assert that leaks of negotiations are an increasingly salient phenomenon, even within the last decade.

[ Figure 1 about here. ]

Secondly, we sought to classify all leaks as either offensive or defensive. Recall that offensive leaks are designed to spur, and defensive leaks to spoil. In most cases, we cannot observe leakers' intent. But we assume that leakers have a good sense of the potential fallout from a leak: they can predict which groups are likely to mobilize. Accordingly, we relied on the original site's treatment of a leak (be it WikiLeaks, or Politico) and information about how a leaked country-position was described in articles on InsideUSTrade and bilaterals.org. If the original site of a leak proclaimed support for (opposition to) the trade deal in question, we coded the leak as offensive (defensive). If the original site used leaked information to make a case for a country's position being insufficiently (overly) liberalizing, we coded the leak as offensive (defensive). We did the same for the coverage in InsideUSTrade and bilaterals.org. If there was no identifiable original source or commentary, we refrained from attributing an offensive or defensive character to the leak. It quickly became apparent, however, that we had little variation to speak of: as opposed to an issue-area like climate change, virtually all leaks in our sample appeared either defensive in character, or unattributable.

${ }^{38}$ It becomes unclear, for instance, if a leaked comment is attached to the individual uttering it, or to the content of the comment, which makes the separation of discrete leaks ambiguous. Moreover, leaked comments vary a great deal in importance, and it is more difficult to distinguish an authorized comment from an unauthorized one. To avoid such issues, we limit ourselves to identifiable leaked documents.
} 
In fact, we found only a single instance where the objective seemed to spur further concessions - or rather, to limit backtracking on past concessions. It concerned a $2015 \mathrm{EU}$ draft proposal in TTIP negotiations that would have allowed individual EU states to restrict imports on the basis of genetically modified organism (GMO) content. The leak disproportionately mobilized groups opposed to the measure, who pushed to maintain the EU's status-quo stance 39 As per our argument above, the structure of trade interests leads us to expect that leaks in trade will be disproportionately defensive: given how constituencies skeptical of deep agreements face a lower collective action problem, and are thus more likely to mobilize, we have argued that elites considering whether to leak are more likely to do this if their aim is to spoil, rather than spur, the agreement. The record of leaks bears out this belief, albeit to an unexpected degree.

[ Figure 2 about here. ]

Third, we examined whether the leak's content related to a particular country. If the leaked document contained a given country's negotiating strategy, its position, or was otherwise explicitly identified as pertaining to a given country, we attributed the leak to that country. While it remains a remote possibility that an opposing negotiating party would have gained access to documents by its negotiating party and chosen to leak them, this seems highly improbable. It is far more plausible that leaked documents about the negotiating position of a given country are disclosed by someone from that country who has ready access to them.

\footnotetext{
${ }^{39}$ InsideUSTrade's report of the leak included only voices critical of the leaked measure, who warned that it would conflict with both the European Single Market, and the WTO's SPS Agreement. Agri-food industry representatives both in the EU and the US cited their opposition, and concern about the uncertainty the leaked measure would create. https://insidetrade.com/node/147257. Last accessed August 20th, 2018.
} 
Figure 1: Leaks per month, 2006-2015

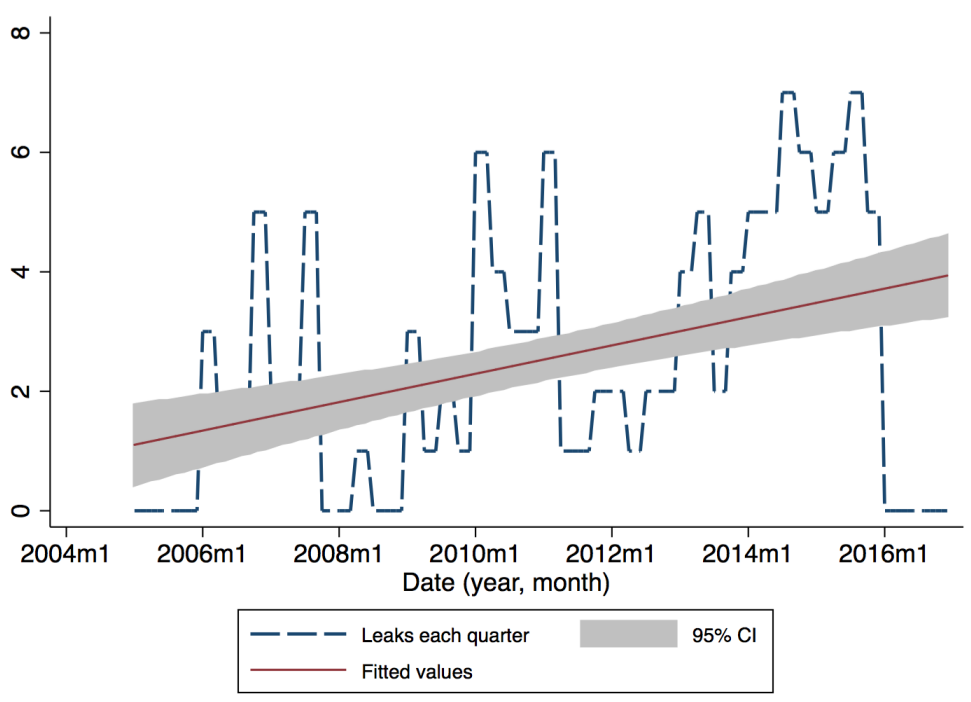

Examining the country attribution, a split is immediately apparent. Of the 120 leaks, 54 can be readily identified with a given country. Of these, 37, or about 69 percent, are attributable to the EU. The other countries to whom documents can be directly attributed are the US, with 8 documents, and New Zealand, with 2 documents. All other countries (such as Canada, Chile, India, Japan, Turkey) have at most a single directly attributable document. While this leaves 65 leaks that cannot be directly attributed, the distribution remains suggestive: a supermajority of attributable leaks appears to implicate the EU.

This apparent overrepresentation of the EU is also consistent with anecdotal evidence, which suggests that the EU is particularly prone to leaks because of an institutional design that gives access to confidential documents to a large number of political officials, and because of the EU's emphasis on internal transparency 40 Actors within the EU Commission, for instance, are pulled between need for confidentiality and secrecy in negotiations and the demand for transparency 41 As noted in its Trade for All strategy, the Commission has promised increased transparency in trade negotiations, a move that was itself a likely reaction to the public mobilization that followed the March, 2014 TTIP leak. While this commitment to greater transparency has been greeted by

\footnotetext{
${ }^{40} ?$.

$41 ?, 44$.
} 
some (such as Giegold himself) with skepticism ${ }^{42}$ it is far from empty rhetoric. The Commission has increased engagement with the European Parliament, is encouraging interaction with Member States and civil society groups, and has committed to impact assessments in 'every significant initiative in the field of trade policy',43

Other states have noted this change, and reacted accordingly. In response to a number of leaks surrounding the TTIP negotiations that the US attributed to the EU, the US refused to grant access to TTIP documents beyond Brussels and US embassies in European capitals: "The U.S. has thus far been unwilling to increase the access to those texts, citing the leaks of restricted EU documents as an indication that the texts would not be secure if available outside of its embassies.' 44 The distribution of directly attributable leaks in our data appears to confirm these suspicions.

Finally, we evaluated the variation in leaks by trade agreement. As Figure ?? illustrates, more than half of all leaks relate to just three trade agreements: the EU-Canada Comprehensive Economic and Trade Agreement (CETA), the EU-US Transatlantic Trade and Investment Partnership (TTIP) and the 12-nation Trans-Pacific Partnership (TPP) agreement. All three of these agreements have attracted attention in large part because of their expanded coverage of new issue-areas in international commerce.

\footnotetext{
${ }^{42}$ The promised 'transparency' around TTIP has been a sham, Aug 31, 2015, TheGuardian.com, www.theguardian.com/commentisfree/2015/aug/31/transparency-ttip-documents-big-business.

${ }^{43}$ ?.

44 "TTIP offers would eliminate 87.5 percent of tariffs on entry into force." November 5, 2015. http://www. bilaterals .org/?ttip-offers-would-eliminate-87-5\&lang=en.
} 
Figure 2: Proportion of leaks accounted for by each trade agreement negotiation

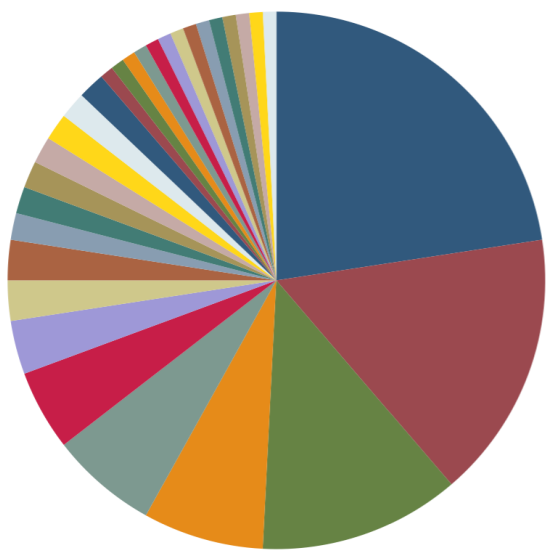

\begin{tabular}{|lll|}
\hline TTIP & TPP & CETA \\
ACTA & EU-India FTA & TISA \\
EU-Pacific EPA & US-Thailand FTA & EU-Central America FTA \\
EU-ASEAN FTA & EU-Caribbean EPA & RCEP \\
EU-Ukraine FTA & EU-SADC EPA & EU-ECOWAS EPA \\
EU-ESA EPA & India-EFTA & Japan-Burma BIT \\
US-Korea FTA & Japan-Philippines EPA & US-Peru FTA \\
EGA & EU-Colombia-Peru FTA & EU-Thailand FTA \\
EU-Singapore FTA & CETA; EU-India; EU-Singapore & India-Japan EPA \\
EU-CEMAC EPA & PACER-plus & Japan-Thailand FTA \\
\hline
\end{tabular}

\subsection{Leaks and Political Party Positions}

We argued above that leaks grow more likely as the distance between a country's position in negotiations and the median position of its domestic audience increases, a view that echoes the earlier observation that leaks may be more likely during times of divided government 45 Leaks are denouncements that play on the discrepancy between popular views and partial negotiated outcomes. In the case of defensive leaks, the more likely a domestic audience is to mobilize following a leak, all else equal, the more likely that leak becomes.

Given how both anecdotal evidence and descriptive statistics suggest that the EU is especially prone to unauthorized leaks, we take a closer look at how EU institutions might be affecting the occurrence of leaks. Within the EU, there are a number of political actors with access to negotiation documents. First are members of DG (Directorate General) Trade - the European Commission's trade ministry - who are charged with negotiating agreements. The Commission reports regularly to the Trade Policy Committee, a working group comprising of senior Member

$$
{ }^{45} ?, 18 .
$$


State officials that is responsible for formulating much of the EU's negotiating positions 46 The TPC, in turn, communicates with Member State permanent representatives to Brussels, who report to the capitals. In addition to this, the Commission reports to Members of the European Parliament (MEPs), through the EP's Internal Trade Committee (INTA), but such consultations are less frequent. Finally, the Commission has established 'reading rooms' that enable representatives from Member States (and other parties) to consult certain trade documents, albeit without any recording devices.

In other words, a large number of EU officials from different institutions have access to trade documents. But not all of these institutional affiliations are likely to explain leaks. Because MEPs are elected only every five years, it is unlikely that variation in the identity of MEPs explains variation in the frequency of leaks over time 47 Moreover, the MEPs that constitute the INTA, unlike members of the TPC, have relatively little trade expertise and would be relatively less likely to engage with trade documents numbering in the hundreds, and often thousands of pages. As the aforementioned Green MEP Sven Giegold put it in the context of the reading-room consultations, "Non-native English-speaking MEPs are ... deterred by highly technical trade-law jargon."48

However, the cues that MEPs receive from national parties do vary over time. Members of European Parliament are also members of national-level political parties, such as the Italian Forza Italia, the French Parti socialiste (PS), or the German Green Party. European political parties in the European Parliament, like the center-right European People's Party (EPP) and the center-left Party of European Socialists (PES), are comprised not of individuals but of these national-level political parties from European Member States. The EPP has consisted historically of Christian democratic parties, although it now comprises other center-right economically liberal and conservative parties (like Forza Italia). The PES comprises social-democrat and socialist parties (like the French PS). And the European Green Party brings together parties supporting green politics (like the German Green Party). European political parties belong in turn to political groups within the European Parliament: the EPP is part of the EPP Group, the PES is part of the Progressive Alliance of Socialists and Democrats (S\&D), and the European Green Party is part of

${ }^{47}$ While there are two European Parliament elections during our period of interest (in 2009 and 2014), data on party manifestos is only available for the 2009 election.

${ }^{48}$ The promised 'transparency' around TTIP has been a sham, Aug 31, 2015, TheGuardian.com, www.theguardian.com/commentisfree/2015/aug/31/transparency-ttip-documents-big-business.
} 
the Greens-European Free Alliance ${ }^{49}$ As such, representation within the EP is organized based on political ideology rather than on the basis of nationality; MEPs work closely with colleagues from similar political parties from across the EU.

Because of this, MEPs are sensitive not only to the electoral politics of their home state, but to the electoral politics within all European Member States. A Green Party MEP such as Sven Giegold would be attuned to the domestic concerns facing Green Party members throughout Europe, including his own German Green Party. Giegold would also be attuned to the demands of voters for parties belonging to the European Free Alliance, such as the Scottish National Party, since the two are coalition partners in the Greens/EFA group.

In sum, MEPs are all members of domestic political parties that respond to the demands of domestic politics. Because the EP groups are transnational and tend to vote together, concerns that register strongly in domestic constituencies will ultimately affect policy positions taken by EP groups. Changes of beliefs among the general population register in national elections, and national parties send cues to corresponding members of the European Parliament. If a domestic constituency suddenly grows wary of liberalization, then we might expect sympathetic MEPs, or officials within parliamentary groups, to become more prone to leak documents that suggest overly ambitious liberalization.

Moreover, even if MEPs are not responsible for leaks, the same dynamics of shifting political positions in Member States would influence other actors involved in trade policy. Although career officials are likely to be less motivated by the demands of domestic audiences than parliamentarians, it is also possible that leaks come from the ranks of Member State representatives in Brussels. Through the TPC and the Member State Permanent Representatives, Member State representatives with high technical expertise in trade negotiations have routine access to negotiation documents.

As such, domestic political preferences comprise our key explanatory variable for the occurrence of leaks. To test our argument, we turn to Party Manifesto data, which we use to calculate the average EU member-country position on trade negotiations. While the party manifesto data comprise a number of measures, we rely on the simplest Left-Right divide, which aptly captures the

\footnotetext{
${ }^{49}$ Very few MEPs are independents - they currently number 21 of the 751 MEPs: http: //www.europarl.europa. eu/meps/en/search.html
} 
different cleavages in trade negotiations 50 Overall, leftist observers are more wary of adjustment costs, more eager to protect a country's "right to regulate", but also more suspicious of intellectual property rights protection, and any measure that shifts power to multinational corporations, like investor-state dispute settlement. Right-wing governments are consistently more bullish on the different dimensions represented by the new set of "deep" trade agreements.

Larger values on this variable indicate more right-leaning positions within domestic audiences and among elected legislators. We thus expect the relationship with leaks to be negative. We use these national means to calculate a EU-wide monthly ideological position. We then regress the number of leaks in every month from 2006 to 2015 on this EU-wide ideological position. This allows us to test whether leaks appear to be a response to variation in domestic beliefs.

We also test beliefs about the relationship between political polarization and leaks. Recall that leaks occur when a policymaker stands to benefit from a discrepancy between popular views and the partly negotiated agreement. Polarization affects both. That is, the more polarized a government is, the more likely it becomes that at least one legislator will be sufficiently disheartened by an aspect of a negotiated agreement. And insofar as polarization among policymakers reflects polarization in the audience, it also means that there is more potential for outrage among the audience following a leak, and thus more likelihood of mobilization. As a result, we expect that leaks increase alongside political polarization. This belief is present in an earlier literature that focused on the relationship between the US press and US government officials (?). Many of the incentives faced by officials over leaks in the domestic context are similar to what we observe in the context of international negotiations. As Abel suggests, "Leaks proliferate in times of controversy and crisis. Although they spring from a variety of motives ... they have one common purpose: to serve the vested interests of the source." 51 Given that leaks are designed primarily to secure a political advantage for the leaker's position, ? also suggests that they will be more likely at times of divided government, when divisions over legislative agendas are likely to be that much more politically salient ${ }^{52}$ To test this belief, we measure polarization using the Party Manifesto dataset

\footnotetext{
${ }^{50}$ See ?. For instance, stringent rules on intellectual property protection amount to additional "market regulation", but they are aggressively pushed by the US, and considered a "liberalizing" measure. The same can be said of geographical indications, traditionally pushed by the EU. To avoid the resulting confusion, we rely on the Left-Right divide.

${ }^{51}$ ?, 2 .

$52 ?, 18$.
} 
as the average distance between the farthest Left and farthest Right party, across all EU states, in a given month.

Table ?? shows the results of our estimations. We also exploit the information obtained from the documents' attributions to different countries, by varying the dependent variable in each estimation. In the first set of results, the dependent variable is thus a monthly count of only those leaks that we can confidently attribute to the EU. The dependent variable in the second set of results is a monthly count of those leaks that could plausibly be attributed to the EU, but which may also have been leaked by another negotiating party. The expectation is that if all unattributed leaks did in fact originate in the EU, then we should see an equal or stronger effect in the second model as in the first. The third set of results then serves as a placebo test: it tests the relationship between EU positions and those leaks we can confidently attribute to countries other than the EU, either because they explicitly implicated other countries, or because they concerned negotiations, like the TPP, that the EU was not party to.

As we would expect if changing domestic positions were indeed fuelling leaks, the effect of EU positions is significant in the first set of results, and then dissipates. In the second set of results, where the dependent variable includes unattributed leaks, the effect of our independent variables is still negative, but no longer statistically significant. In the third set, showing our placebo results, Left-Right party ideology and Left-Right polarization remain entirely insignificant. The upshot is that EU-attributed leaks do appear significantly related to domestic political preferences, as proxied by elected parties' platforms. The model shows good fit. By converting the count dependent variable to a dummy variable, coded as 1 if any leaks occurred in that month, and 0 otherwise, we can re-estimate the relationship with a logit model, to offer a more intuitive sense of how well the model fares. In the case of the second model where we include Right-Left party ideology and Right-Left polarization, the logit model (not shown) correctly classifies over 76 percent of cases. Substantively speaking, these are large effects: looking at EU-attributed leaks, a standard deviation increase in left-leaning parties is associated with an increase of $66.3 \%$ in the number of leaks, all else equal. Polarization shows a similarly important effect: a standard deviation increase in polarization is associated with a $60.3 \%$ increase in the number of leaks.

Judging by the drop in significance of the coefficients from the first set of results to the second set of results, we can conclude that the unattributed leaks do not originate entirely in 
the EU. As for our placebo test in the third set of results, it suggests that our first estimation is indeed catching an EU-specific relationship between Left-Right party ideology and leaks, rather than salient events during trade negotiations.

Because leaks are increasing over time, there may be a concern that the correlation between party ideology and leaks is spurious, if party ideology varies in a linear fashion with time. If this is the case, the results in Table ?? may simply be reflecting a catholic increase in the number of leaks over time. To control for this possibility, we re-run our main model (Model 2) with cubic splines over the ten-year time period for which we have data. We also de-trend the variables by regressing them on time and rerunning the regression using residuals. These results are presented in columns 3,4 , and 5, respectively. In columns 4 and 5, the dependent and independent variables are the residuals resulting from detrending. The results remain consistent with our expectations. The one unexpected result in Table 1 is the positive correlation between increased representation of the European Left and the incidence of non-EU leaks in Model 3, where we account for time using cubic splines. While the effect on this placebo estimation is the opposite from the expectation in our EU-attributed sample, our theory offers no explanation for this anomaly, which we treat as such. This result does not hold in the two alternative models in which we control for time by de-trending our variables.

There may be a concern about the proportion of zeros in the sample: $41 \%$ of months in our dataset feature no leak. As a robustness check, we use a zero-inflated negative binomial model, which estimates the likelihood of non-events. Our outcome variable in this model is once again EU-attributed leaks, and our main explanatory variables are the same as before. We predict non-events using the number of negotiating rounds for CETA and TTIP (the most leaked EU agreements) in a given month, and the mean level of protectionist sentiment in Europe. The results, in Table ??, remain consistent. Our two variables accounting for non-events point in the expected direction, though they fall short of significance. Most importantly, however, EU-attributed leaks are associated with greater representation of the political Left, and greater Left-Right political polarization. The Vuong test supports the good fit of the zero-inflated model, compared to a standard negative binomial estimator.

Overall, stronger representation of the political Left in Europe appears to be associated with a greater incidence of trade negotiation leaks. And as divisions between Left and Right grow, 
Table 1: Predicting EU leaks

\begin{tabular}{|c|c|c|c|c|c|}
\hline \multirow[b]{2}{*}{ Model } & \multicolumn{4}{|c|}{ DV: EU-Attributed Leaks } & \multirow[b]{2}{*}{$\begin{array}{c}\text { Detrended II } \\
(5) \\
\end{array}$} \\
\hline & $(1)$ & $(2)$ & $\begin{array}{c}\text { Cubic Spline } \\
\text { (3) }\end{array}$ & $\begin{array}{c}\text { Detrended I } \\
(4)\end{array}$ & \\
\hline Mean Right-Left & $\begin{array}{l}-0.23^{* *} \\
(0.11)\end{array}$ & $\begin{array}{c}-0.24^{* * *} \\
(0.09)\end{array}$ & $\begin{array}{c}-0.47^{* * *} \\
(0.14)\end{array}$ & $\begin{array}{c}-0.06^{* *} \\
(0.02)\end{array}$ & $\begin{array}{l}-0.34^{*} \\
(0.18)\end{array}$ \\
\hline Mean R-L Political Polarization & & $\begin{array}{c}0.13^{* * *} \\
(0.05)\end{array}$ & $\begin{array}{l}-0.14 \\
(0.13)\end{array}$ & $\begin{array}{c}0.03^{* * *} \\
(0.01)\end{array}$ & $\begin{array}{l}0.15^{* *} \\
(0.05)\end{array}$ \\
\hline Constant & $\begin{array}{c}-2.04^{* * *} \\
(0.41)\end{array}$ & $\begin{array}{c}-7.73^{* * *} \\
(1.99)\end{array}$ & $\begin{array}{c}-43.57^{* * *} \\
(11.58)\end{array}$ & $\begin{array}{c}0.01 \\
(0.04)\end{array}$ & $\begin{array}{c}0.17 \\
(0.27)\end{array}$ \\
\hline \multirow[t]{2}{*}{ Cubic Spline } & No & No & Yes & No & No \\
\hline & \multicolumn{4}{|c|}{ DV: Potential EU Leaks } & $(5)$ \\
\hline Mean Right-Left & $\begin{array}{l}-0.05 \\
(0.09)\end{array}$ & $\begin{array}{l}-0.05 \\
(0.10)\end{array}$ & $\begin{array}{l}-0.08 \\
(0.15)\end{array}$ & $\begin{array}{l}-0.02 \\
(0.04)\end{array}$ & $\begin{array}{l}-0.06 \\
(0.18)\end{array}$ \\
\hline Mean R-L Political Polarization & & $\begin{array}{l}-0.01 \\
(0.05)\end{array}$ & $\begin{array}{c}0.04 \\
(0.23)\end{array}$ & $\begin{array}{l}-0.01 \\
(0.02)\end{array}$ & $\begin{array}{l}-0.02 \\
(0.10)\end{array}$ \\
\hline Constant & $\begin{array}{c}-1.01^{* * *} \\
(0.32)\end{array}$ & $\begin{array}{l}-0.46 \\
(2.43)\end{array}$ & $\begin{array}{l}-10.57 \\
(17.96)\end{array}$ & $\begin{array}{c}0.01 \\
(0.10)\end{array}$ & $\begin{array}{c}0.03 \\
(0.41)\end{array}$ \\
\hline Cubic Spline & No & No & Yes & No & No \\
\hline & $(1)$ & $\begin{array}{l}\text { DV: } \\
(2)\end{array}$ & $\begin{array}{c}\text { on-EU Leak } \\
(3)\end{array}$ & $(4)$ & $(5)$ \\
\hline Mean Right-Left & $\begin{array}{c}0.03 \\
(0.16)\end{array}$ & $\begin{array}{l}-0.01 \\
(0.16)\end{array}$ & $\begin{array}{c}0.41^{* * *} \\
(0.15)\end{array}$ & $\begin{array}{c}0.02 \\
(0.03)\end{array}$ & $\begin{array}{c}0.26 \\
(0.16)\end{array}$ \\
\hline Mean R-L Political Polarization & & $\begin{array}{c}0.11 \\
(0.11)\end{array}$ & $\begin{array}{l}-0.17 \\
(0.20)\end{array}$ & $\begin{array}{c}0.02 \\
(0.02)\end{array}$ & $\begin{array}{c}0.11 \\
(0.11)\end{array}$ \\
\hline Constant & $\begin{array}{c}-1.24^{* * *} \\
(0.41)\end{array}$ & $\begin{array}{l}-6.21 \\
(4.90)\end{array}$ & $\begin{array}{l}30.52^{*} \\
(18.35)\end{array}$ & $\begin{array}{l}-0.02 \\
(0.05)\end{array}$ & $\begin{array}{l}-0.15 \\
(0.24)\end{array}$ \\
\hline Cubic Spline & No & No & Yes & No & No \\
\hline $\mathrm{N}$ & 117 & 117 & 117 & 117 & 117 \\
\hline
\end{tabular}

Note: Table presents results from Poisson regressions. DV is a count of leaks each month. DV in column 4 is the residuals of leaks on time. DV in column 5 is working residuals.

${ }^{*} p<0.10,{ }^{* *} p<0.05,{ }^{* * *} p<0.01$ 
Table 2: Zero-inflated model for EU CETA and TTIP leaks

\begin{tabular}{lc}
\hline \hline & EU-Attributed Leaks \\
\hline Accounting for EU-Attributed Leaks & \\
& \\
Mean Right-Left & $-0.24^{* *}$ \\
& $(0.12)$ \\
Mean R-L Political Polarization & $0.15^{* *}$ \\
& $(0.07)$ \\
Constant & $-7.97^{* * *}$ \\
& $(3.09)$ \\
\hline Accounting for zero leaks & \\
& \\
Monthly CETA and TTIP negotiations & -2.27 \\
& $(3.89)$ \\
Mean protectionist sentiment & -9.13 \\
& $(6.18)$ \\
Constant & 2.64 \\
& $(1.73)$ \\
\hline $\mathrm{N}$ & 117 \\
\hline \hline Vuong test of zinb vs. standard negative binomial: $\mathrm{z}=18.47 \operatorname{Pr}>z=0.000$. \\
${ }^{*} p<0.10,{ }^{* *} p<0.05,{ }^{* * *} p<0.01$
\end{tabular}

so does the occurrence of leaks.

\subsection{Leaks and agreement issue-areas}

The results above do not distinguish what aspect of the agreement is leaked. But our theory holds additional testable implications in this regard. If leaks of trade negotiations are strategic denouncements - if their aim is to mobilize domestic audiences against parts of an agreement - then we should expect them to target those parts of agreements that are least established, and most in flux.

In a first cut at this question, we code the different chapters of each agreement according to whether they belong to the pre-WTO or post-WTO era. The institutional passage from the GATT to the WTO, which took place in 1995, marked the expansion of the trade regime from a realm concerned mostly with tariffs and simple non-tariff barriers to one that covered a range of other issues, including services, intellectual property rights, sanitary and phytosanitary (health) standards, and technical barriers to trade. This expansion of the trade regime has been written 
about extensively elsewhere 53 but its importance from our standpoint is that it allows us to neatly divide older, more established areas of trade negotiations, from newer, less settled areas of negotiation.

Chapters like dispute settlement, though potentially controversial since it grants governments the ability to formally challenge the domestic policies of other governments, have been woven into agreements since the 1950s, and have thus converged on common formulations. The same goes for trade remedies, which concern the sensitive matter of when countries can escape their obligations. These lead to more than one third of trade disputes in the WTO, but the corresponding legal text has long been established. These older areas are less in play than more recent issues, such as technical barriers to trade, or intellectual property rights. Our expectation is that leaks should target unsettled issues that are still in flux 54 since this is where leakers expect to have the biggest effect on negotiation outcomes. These sections are more malleable than those that rely on long-existing texts taken from other agreements.55

[ Figure 3 about here. ]

Figure 3: Leaks divided by Pre- and Post-WTO issue-areas

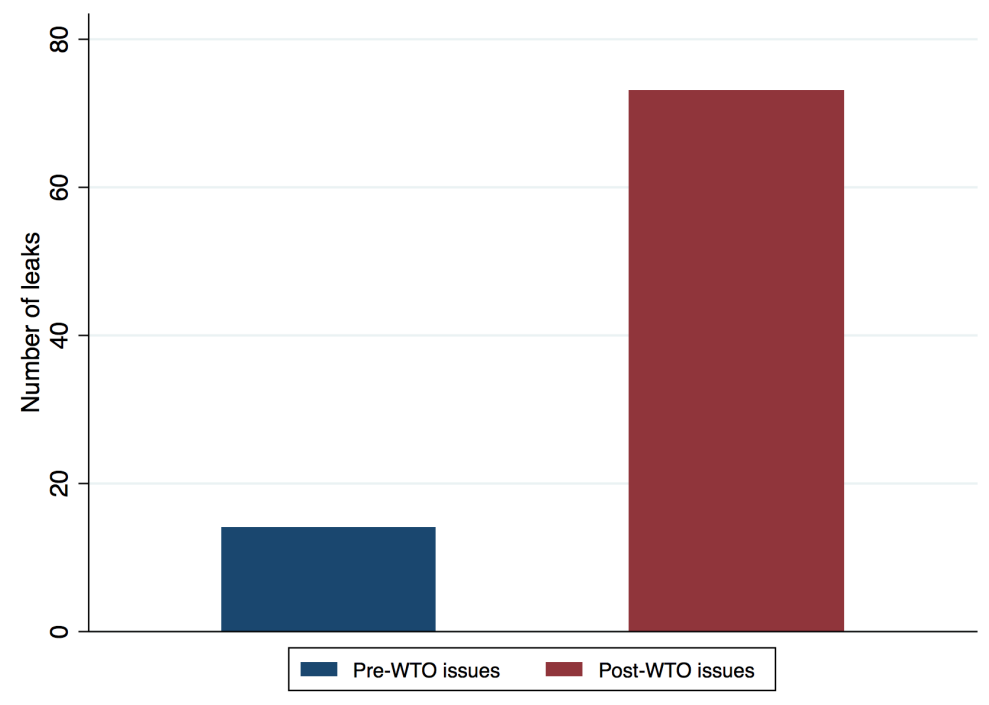

\footnotetext{
${ }^{53} ? ?$.

${ }^{54} ?$.

${ }^{55}$ Allee and Elsig 2016.
} 
The distribution of leaks across different areas is striking. Figure ?? shows that of those leaks in our database that were about a specific issue, the overwhelming majority relate to issueareas that have only recently been covered by negotiations in the international trade regime 56 Consistently with the theory, it is those issues that remain in flux that are subject to the greatest number of leaks.

Figure ?? shows the full breakdown issue-areas that have been the subject of the most leaks. Again, the results are striking in their asymmetry. Were leaks random, or simply a function of the supply of available documents, we would expect a relatively even distribution of leaks over issue-areas. The skewed distribution suggests instead that leaks are strategic, targeting a select number of issue-areas with greater frequency. Of all the leaks in our database, more than a third $(36 \%)$ pertain to intellectual property. Services and investment also each have a relatively high proportion of leaks - around twice the number relating to market access for goods.

[ Figure 4 about here. ]

Figure 4: Leaks by issue-area, 2006-2015

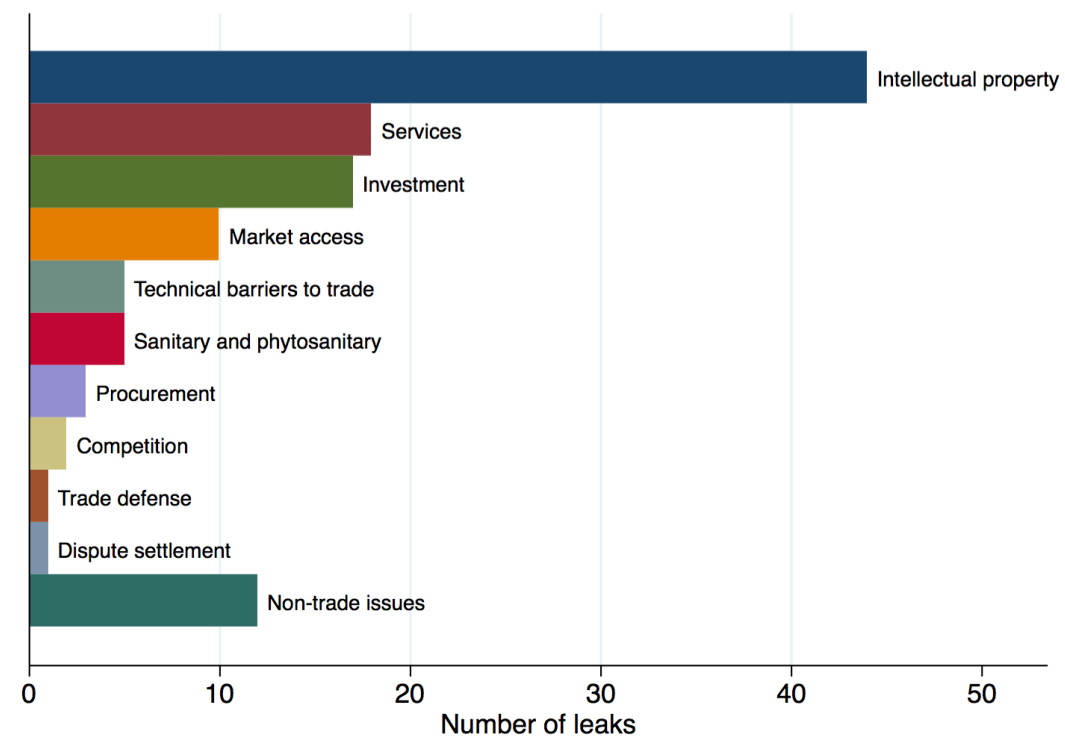

\footnotetext{
${ }^{56}$ Because some leaks relate to multiple issue-areas, it is possible for a single leak to appear in both columns. These data do not include the 31 leaks that were 'general' leaks relating to, for instance, an entire trade agreement, or to a country's negotiating mandate.
} 


\subsection{Political Effects of Leaks}

Our discussion has focused on why leaks occur. We argue that in the case of trade negotiations, leaks are defensive: political actors leak in order to mobilize constituents who are opposed to changes, with an aim to reducing the concessions made. For this reason, leaks target parts of trade agreements that are most in flux, and become most likely during political shifts to the left, and at times of greater political polarization. If all this is true, however, we should expect that leaks have observable political effects - that the strategic action, in other words, sometimes pays off. This is what we examine below.

We have already considered the March 2014 leak of the EU's German-language negotiating mandate for TTIP. Here the leaker, a member of the European Parliament, happened to be known. The same event also aptly demonstrates the effects of leaks. This single leak reverberated through subsequent negotiations. The leak, which occurred on March 7 through a website dedicated to the dissemination of leaked EU documents, coincided with an EU-based negotiating round for TTIP (March 10-14) as well as the May 2014 European Parliament elections57 The leak was highly publicized, and was followed with large public demonstrations against TTIP, including a large anti-TTIP rally on 13 March at which a member of a civil society organization co-founded by Giegold spoke against the agreement.

The leak also fed intense public debate over the investor-state dispute settlement process, prompting the German federal government to withdraw its support for ISDS' inclusion in TTIP 58 This opposition to ISDS did not abate until the EU proposed a new investment court system for use in TTIP and other trade agreements, designed to safeguard states' autonomy to regulate in the public interest from an ad hoc judicial system prone to frivolous claims 59 What is more, debate on this issue spilled back onto CETA negotiations with Canada 60 Following the leak of the draft CETA text on 1 August 2014 (discussed below), the German Green party governing in coalition in

\footnotetext{
${ }^{57}$ The website www.ttip-leak.eu was launched in collaboration with the civil society organization PowerShift and advertises the Greens-European Free Alliance EP political group in its banner. Green MEPs Sven Giegold, Rebecca Harms and Ska Keller put their names to the leak and provided commentary on the leaked negotiating mandate.

${ }^{58}$ Shawn Donnan and Stefan Wagstyl, 15 March 2014 "Transatlantic trade talks hit German snag", Financial Times, https://www.ft.com/content/cc5c4860-ab9d-11e3-90af-00144feab7de

${ }^{59}$ See ?. "Commission proposes new Investment Court System for TTIP and other EU trade and investment negotiations." Sep 16, 2015, Commission Press Release, Europa.eu, http://europa.eu/rapid/press-release_ IP-15-5651_en.htm.

00 "EU-Canada pact faces German opposition over investor clauses." Sep 25, 2014, EUObserver.com, https:// euobserver.com/news/125764.
} 
North Rhine Westphalia threatened to block the CETA deal. In an unprecedented move, the EU then approached Canada to request renegotiation of the investment provisions in the completed CETA agreement 61 In this way, a leaked document appeared to have visible long term effects, spoiling negotiations in a way that limited commitments made.

What is more, Giegold's TTIP leak also marked the beginning of overt involvement of Greens/EFA MEPs in leaking of EU documents. Giegold and other MEP colleagues launched an "EU leaks" portal in September 2016, the aim of which is explicitly to influence policy in the EU 62 As an explanatory document produced by the Greens/EFA group notes in explaining the rationale for developing a leaks platform, "whilst several media outlets and not-for-profit organisations have already established their own secure platforms, we have insider knowledge of the functioning of the EU, which gives us a strategic advantage to know how to handle the information we receive and how best to get a concrete impact in policy terms." 63

How does a leak of negotiated documents shift power towards those actors opposed to the negotiations? To examine the process by which this takes place, we took a closer look at another salient leak, the August 2014 leak of CETA negotiating documents to German media. There is every reason to believe that the CETA case is one more example of a defensive leak on the European side. Yet it provides us with an ideal setting to study the effects of the leak in Canada, where we were able to obtain all email correspondence (over 50 pages) between Canadian trade officials during the 48 hours following the leak 64 Because of the relative symmetry between the two negotiating parties on key sensitive issues - both sides value cultural protection, both elevate environmental protection relative to countries like the US, but both also face a domestic split over issues of intellectual property and investor-state protection - there is good reason to suspect that the domestic effects of the leak would be comparable.

The first thing the internal exchanges on the Canadian side reveal is the considerable awareness by officials of the domestic pushback that was to follow. These concerns proved well founded. The day following the leak, for instance, the Canadian trade ministry received multiple

\footnotetext{
61 "EU quietly asks Canada to rework trade deal's thorny investment clause." Jan 21, 2016, CBC.com, http: //www.cbc.ca/news/politics/canada-europe-trade-isds-ceta-1.3412943

${ }^{62}$ https://sven-giegold.de/launch-of-the-eu-leaks-platform/

63 "EU Leaks: Frequently Asked Questions," https://www.greens-efa.eu/files/doc/docs/ fb52de9dcec822658438724d52fc4782.pdf

${ }^{04}$ Documents obtained through a Canadian Access to Information (ATIP) request.
} 
requests from the Canadian wine industry for clarification on the CETA concessions made by Canada regarding alcohol. These queries came in the wake of media stories that claimed "Canada's wine industry may face restrictions if leaked EU trade deal is accurate." 65 In this specific news article, which Canadian trade officials circulated among themselves, Canada's CTV News reported that if the leaks were accurate, then Canada's wine industry would "face restriction," since CETA would be "limiting the number of privately run outlets selling domestic products." This turned out to be a misrepresentation; the restriction only concerned stores that sold exclusively Canadian wine, i.e. that were themselves inherently discriminatory. And the limit of 60 private outlets in British Columbia came at a time when only 21 such stores were operating, meaning that the CETA agreement not only formalized the continued existence of discriminatory Canadian businesses, but actually allowed for their expansion 66 But these details were not disclosed in the news coverage.

As the CTV article admitted, moreover, since the leak was thought to be a partial one 67 it was impossible to gauge what the EU had offered in exchange: "The leaked document was not posted in its entirety, so it's not known how much cheaper European wine and other products will be for Canadians." This aptly illustrates the effects of selective leaks. By highlighting concessions without showing the benefits obtained in exchange, leaks risk mobilizing affected actors on a single side of the debate: consumers who stand to gain from reciprocal concessions often do not find out what these concessions yielded 68

In this case, the trade ministry's internal correspondence shows communications offices scurrying to point to existing documents showing that Canada had long agreed to "keeping the existing number of private wine stores". But the harm was done, and the claim was reproduced in industry publications under increasingly threatening headlines, e.g.: "Leaked trade deal threat to Canadian wine.' 69 This inability to contain the reaction to leaks does not occur by happenstance. Leaks lead to a shift in control over the agreement's portrayal. In the normal course of negotiations, governments get the first shot at "selling" an agreement when it is unveiled. It is a standard part

\footnotetext{
${ }^{65} \mathrm{http}$ // www.ctvnews.ca/politics/canada-s-wine-industry-may-face-restrictions-if-leaked-eu-trade-deal-isaccurate-1.1960876. Last accessed Dec 15, 2017.

${ }^{66} \mathrm{http}: / /$ globalnews.ca/news/1508959/leaked-document-of-eu-canada-trade-agreement-could-affect-b-c-only-winestores/. Last accessed Dec 15, 2017.

${ }^{67}$ It later turned out to include all negotiating documents: as Canadian officials described the leak in internal correspondence, "this is the full consolidated text as authenticated by [two names withheld], minus the 'attached separately' documents from the table of contents."

${ }^{68}$ ?, 243 suggests leaks lead to "informational advantages" for targeted groups.

${ }^{69}$ http://www. thedrinksbusiness.com/2014/08/leaked-trade-deal-threat-to-canadian-wine/
} 
of the two-level aspect of international negotiations. Negotiators agree to a given bargain, and then each side lets the other present its terms under a positive light to its own domestic audience in a way that facilitates ratification. But in the wake of leaks, the political opposition and opponents of the agreement exert far more control over the discourse. This is because governments commonly refuse to comment on leaks, to avoid legitimizing them or elevating the status of leakers, both of which might increase the practice of leaking. Following the CETA leak, the Canadian Trade Ministry responded to specific requests for information from industry, but they were unable to make these responses public, since they kept to the stance, repeated in dozens of internal emails over a 48-hour period, that "Canada does not comment on leaks of purported negotiating texts". When asked about the implications of the leaked CETA text for Canadian industries, Canadian Justice Minister Peter MacKay likewise responded, "I'm not going to comment on a leak. Leaks by their very nature may or may not be accurate." This stance by governments is commonplace, but it has overlooked consequences on how the social impact of treaties is presented. While governments avoid commenting, opponents to the agreements mobilize and capitalize on the leak to denounce the underlying agreement. As a result, leaks generate particular framing effects.

\subsection{News Coverage: Evidence of Asymmetry?}

The possibility of asymmetric coverage leads us to test the claim in its broader form. Is the portrayal of a negotiated agreement less favorable when it results from a leak than when it is released in the normal course of negotiations, even as it concerns the very same text?

We address this question in the case of the aforementioned CETA leak, which provides us with a natural case: since the full consolidated text was leaked in August 2014, and then officially released once the agreement was concluded in September 2014, it offers us as clean a comparison as we might hope for between two types of "releases": the text remained the same, the two events were very close in time - only the manner in which the text was unveiled differed.

To perform this comparison, we collected all Canadian news articles mentioning 'CETA', as indexed by the website Factiva, for a period of three days following the release of the leaked CETA text, and the release of the official text. This resulted in 33 articles, 11 of which were published between August 13 and August 15, 2014 following the leak of the negotiating text, and 22 of which were published between September 26 and September 28, 2014 following the official release 
of the CETA text. We begin by manually coding all positive and negative statements made about the CETA agreement by the government, opposition groups, and NGOs, in each article following both types of releases. As Table 2 shows, only three of 11 articles following the leak included a positive comment about the CETA agreement made by the government, while 14 of 22 articles following the official release included a positive comment. Similarly, over $36 \%$ of the coverage of the leaked version cited negative NGO views, compared to less than $14 \%$ for the coverage of the official releases. In sum, even when the negotiated legal text is the same, its coverage offers voice to different political actors in the wake of a leak versus an official release. Government incentives are such that leaks offer disproportionately more voice to opponents of the agreement.

Table 3: Government framing of leaked and officially-released text

\begin{tabular}{lccr}
\hline \hline & \multicolumn{3}{c}{ Statements by government } \\
News coverage & No positive statement & Positive statement & Total \\
\hline Leak coverage & 8 & 3 & 11 \\
Official release coverage & 8 & 14 & 22 \\
Total & 16 & 17 & 33 \\
\hline \hline
\end{tabular}

Note: Pearson's Chi-square $=3.8824 ; \operatorname{Pr}=0.049$; Cramér's V=0.3430.

Does the overall valence of the news coverage follow these differences in the sources cited? To find out, we use a dictionary-based approach to identify words associated with positive and negative sentiment in news articles. We create two samples of thirty sentences (the average length of the news articles we collected), drawn randomly from the 11 leak-related and 22 official releaserelated articles, respectively 70 We then identify positive and negative words in the two samplessubtracting negative from positive words gives a net sentiment score 71 We repeat this operation 200 times and store the resulting sentiment score each time, so as to be able to report sensible margins of error.

[ Figure 5 about here. ]

The resulting average sentiment for coverage of the leaked CETA text ranged from -13.0 (2.5\% confidence interval) to 12.0 , (97.5\% confidence interval), with a mean score of -0.38 . The

\footnotetext{
${ }^{70}$ Using random sampling is important to address issues of selection. There may be news articles relating to CETA that were not indexed by Factiva, and we cannot know the distribution of positive and negative words in these articles, or indeed in potential, but unwritten articles.

${ }^{71}$ We use the Bing dictionary in the Tidy Text package in R.
} 
Figure 5: Sentiment of news coverage on leaked and officially-released CETA texts

(a) Leak coverage

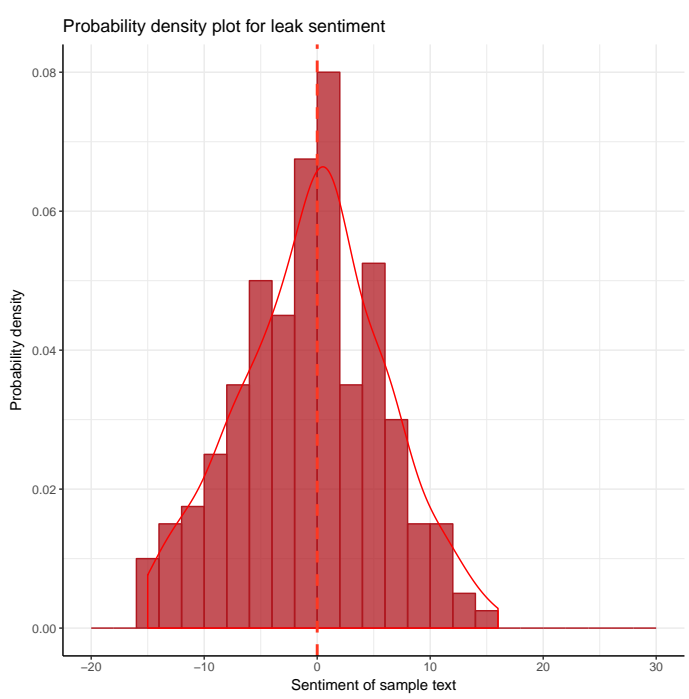

(b) Release coverage

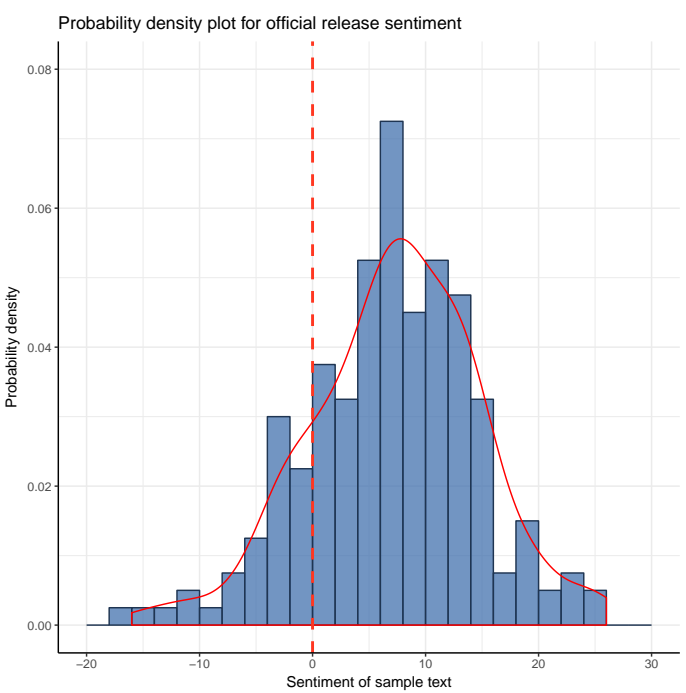

sentiment in the coverage of the official government release ranged from -8.1 (2.5\% confidence interval) to 22.1 (97.5\% confidence interval), with a mean score of 7.3. Figure ?? displays the distribution of sentiment over the different sampled texts. A t-test confirms that the difference is highly significant: mean sentiment for coverage of leaked CETA texts (-0.38) is significantly more negative than for the coverage of the officially-released CETA text (7.3).

Insofar as leaks in trade negotiations are defensive in nature, as we argue, they appear to achieve their aim: they draw attention to the most malleable aspects of trade agreements, and they achieve the desired framing. When considering both the type of sources cited and the sentiment analysis, the coverage of leaked texts is significantly more negative on the underlying agreement than the coverage of the same text's official release.

The comparison remains necessarily imperfect: the official release naturally occurred after the leak, and so may have been affected by it. The direction of this effect is theoretically ambiguous: in part, our reasoning suggests that reactions to the official release would have been more negative because of the prior framing of the debate following the leak, which would render our assessment of the difference in coverage more conservative. The main point to note in this regard is that the text did not change between the leak and the official release, because the two occurred a month apart, which would not have been sufficient time to amend negotiated text. The leak had disclosed the final version. While not perfect, the case of the 2014 CETA leak thus offers us as clean a 
comparison as we might hope for.

\section{Conclusion}

In the past decade, leaks have become a prominent fixture of international negotiations. We begin by demonstrating that this is no bias of perception: the increasing attention to leaks reflects a real increase in their occurrence. We then present a theory of leaks that explains this rise. Far from being random events or deeds of opportunity, we argue that leaks are used strategically in order to influence negotiations. The theory distinguishes between two types of leaks. Where offensive leaks are designed to spur a recalcitrant party to commit to more, defensive leaks are designed to claw back commitments made. In both cases, leaks are driven by the distance between a negotiating text and the preferences of domestic audiences. As this distance increases, so does the probability of a leak. We also argue that leaks are likely to target parts of agreements that remain in flux in international law. It is in these unsettled areas that leaks may have the greatest effect.

To assess our claims, we turn to the empirical case of the international trade regime - an area of international politics where leaks have grown especially salient. We assemble the first comprehensive dataset on leaked documents from international trade agreement negotiations, covering leaks from a ten-year period, spanning 2006 to 2015. We examine the distribution of leaks by agreement, by country, and by issue-area. The results are compelling. As our theory predicts, leaks are overwhelmingly concentrated in those areas of the international trade regime that were not covered by the GATT, and that only appeared as issues for negotiation after 1995. As we show, the vast majority of leaks pertain to intellectual property, services, and investment, and leave out other salient, but more legally established areas, such as dispute settlement between member-states, trade remedies, or security exceptions.

The second set of results focuses on the European Union, which our data show is responsible for a supermajority of all attributable leaks. The EU's growing emphasis on transparency in its trade negotiations, combined with an institutional structure involving many veto players, seem to account for the prominence of leaks of EU documents. This large number of leaks from the EU affords us an opportunity to test the belief that leaks are driven by the distance between negotiation documents and the preferences of domestic audiences. Using data on European political party 
manifestos to measure changing ideological positions on issues that pertain to trade negotiations, we find that the incidence of leaks is significantly correlated with opposition to economic liberalization within the average European political party.

We also take a closer look at the reaction to a specific leak, during the 2014 CETA negotiations. We show how Canadian industries quickly mobilized in the face of an alleged concession, and how the Canadian government was kept from publicly responding to the leak, from fear of legitimizing it. We then show that these incentives produce asymmetric news coverage of negotiated outcomes: comparing the CETA leak to the subsequent official release of the same treaty, we show that the coverage of agreements following a leak relies on a greater number of opposing sources, and a lower number of supporting ones. When we perform a sentiment analysis on the entire CETA media coverage, we find that the news articles covering the leak are systematically more negative in tone than those covering the official release of the very same text.

We have purposefully left open the normative question over the social welfare effects of leaks, and focused on their causes and effects. But our discussion affords us one normative consideration. Insofar as leaks are targeted, in the sense that they expose some parts of negotiations but not others, they recall ?'s "Cautionary Note."72 7 There, the authors argued that legalization of international agreements, by making it clearer who gains and who loses from liberalization, will ultimately lead to more mobilization against the agreement, at a cost to the median voter. In our case, if leaks only expose specific concessions, without revealing the overall bargain they pertain to, they may have similar effects, leading to mobilization against what could prove beneficial agreements in the aggregate. For instance, a reduction of rules-of-origin requirements on autos from 60 percent to 45 percent may hurt auto exporters, but the reciprocal commitments made in exchange may benefit all agricultural exports. If the 45 percent concession is the target of a leak, it may lead to mobilization that blocks negotiations, despite the fact that these would have proven overall beneficial. Our examination of the asymmetric media coverage in the wake of the CETA leak provides additional support for this view. By not revealing the quid pro quo that characterizes all international negotiations that deal with more than one issue, leaks may ultimately block welfareenhancing reforms. In sum, the targeted nature of leaks may work against the median voter's interests.

\footnotetext{
${ }^{72}$ More recently, see ? for an analogous argument linking increased transparency with a decrease in cooperation.
} 
Taken together, our results allow us a fuller picture of leaks in international negotiations. When it comes to the trade regime, the average leak is of a defensive, rather than offensive character. The greater the discrepancy between popular views and partial negotiated outcomes, the greater the odds of a leak. And because leaks seek to affect the content of agreements, they target those provisions which are the least settled in law, and thus the most open to influence. Insofar as trade agreements continue to regulate measures that traditionally fall under sovereign control, leaks in international negotiations are likely to remain frequent. In part, this is because they work. As we show, leaks are successful in shifting the framing of the debate, generating significantly more negative coverage of the underlying treaty, as compared to official releases of the agreement, even when dealing with the same text. In sum, leaks during negotiations are strategic political moves that seek to reshape the content of international agreements. 


\section{References}

Abel, Elie. 1987. Leaking: Who Does it? Who benefits? At what costs? New York: Priority Press.

Bovens, Mark A. P., Henk Geveke, and Jouke de Vries. 1995. "Open Public Administration in the Netherlands: The Politics of Leaking." International Review of Administrative Sciences 61(1): $17-40$.

Busch, Marc L, and Eric Reinhardt. 2005. "Industrial location and voter participation in Europe." British Journal of Political Science 35(4): 713-730.

Busch, Marc L., and Eric Reinhardt. 2006. "Three's a Crowd: Third Parties and WTO Dispute Settlement." World Politics 58: 446-477.

Busch, Marc L., and Krzysztof J. Pelc. 2019. "Words Matter: How WTO Rulings Handle Controversy." 63(2).

Carnegie, Allison, and Austin Carson. 2018. "The Spotlight's Harsh Glare: Rethinking Publicity and International Order." International Organization forthcoming.

Commission, European. 2015. Trade for all: towards a more responsible trade and investment policy. Technical report European Commission.

Davidson, Sandra. 2011. "Leaks, Leakers, and Journalists: Adding Historical Context to the Age of WikiLeaks." Hastings Communication and Entertainment Law Journal 34: 27.

Davis, Christina L. 2004. "International Institutions and Issue Linkage: Building Support for Agricultural Trade Liberalization." American Political Science Review 98(1): 153-169.

de Jong, Jurgen, and Michiel de Vries. 2007. "Towards Unlimited Transparency? Morals and Facts concerning Leaking to the Press by Public Officials in the Netherlands." Public Administration and Development 27(3): 215-25.

De Mestral, Armand. 2015. "When Does the Exception Become the Rule? Conserving Regulatory Space under CETA." Journal of International Economic Law 18(3): 641-654.

Elliott, Kimberly. 2016. "How Much "Mega" in the Mega-Regional TPP and TTIP: Implications for Developing Countries.".

Finnemore, Martha, and Kathryn Sikkink. 1998. "International Norm Dynamics and Political Change." International Organization 52(4): 887-917.

Flynn, Kathryn. 2011. "The practice and politics of leaking." Social Alternatives 30(1): 24-28.

Goldstein, Judith, and Lisa L. Martin. 2000. "Legalization, Trade Liberalization, and Domestic Politics: A Cautionary Note." International Organization 54: 603-632.

Haas, Ernst B. 1980. "Why Collaborate? Issue-Linkage and International Regimes." World Politics $32(3): 357-405$.

Hafner-Burton, Emilie M., and David G. Victor. 2016. "Secrecy in International Investment Arbitration: An Empirical Analysis." Journal of International Dispute Settlement 7(1): 161-182. 
Hafner-Burton, Emilie M., Zachary C. Steinert-Threlkeld, and David G. Victor. 2016. "Predictability versus Flexibility: Secrecy in International Investment Arbitration." World Politics 68(3): 413-453.

Herrmann, Christoph. 2015. "Transleakancy." In Trade Policy between Law, Diplomacy and Scholarship: Liber amicorum in memoriam Horst G. Krenzler, ed. Christoph Herrmann, Bruno Simma, and Rudolf Streinz. Online: Springer pp. 39-46.

Hillebrandt, Maarten Zbigniew, Deirdre Curtin, and Albert Meijer. 2014. "Transparency in the EU council of ministers: An institutional analysis." European Law Journal 20(1): 1-20.

Johns, Leslie, and Krzysztof J. Pelc. 2014. "Who Gets to Be in the Room? Manipulating Participation in WTO Disputes." International Organization 68: 663-699.

Johns, Leslie, and Krzysztof J Pelc. 2016. "Fear of Crowds in WTO Disputes: Why Don't More Countries Participate?" Journal of Politics 78(1): 88-104.

Johns, Leslie, Krzysztof Pelc, and Rachel Wellhausen. 2019. "How a Retreat from Global Economic Governance May Empower Business Interests." Journal of Politics 81(2): 731-738.

Jönsson, Christer. 2002. "Diplomacy, bargaining and negotiation." Handbook of international relations pp. 212-234.

Koremenos, Barbara, Charles Lipson, and Duncan Snidal. 2001. "The Rational Design of International Institutions." International Organization 55: 761-799.

Kucik, Jeffrey, and Krzysztof J Pelc. 2016. "Over-commitment and backsliding in international trade." European Journal of Political Research 55(2): 391-415.

Kurizaki, Shuhei. 2007. "Efficient secrecy: Public versus private threats in crisis diplomacy." American Political Science Review 101(3): 543-558.

Kurizaki, Shuhei, and Taehee Whang. 2011. Inferring Secret Diplomacy. Technical report Version 1.1, Working Paper. Texas: Texas AM University.

Manger, Mark S. 2009. Investing in protection: The politics of preferential trade agreements between north and south. Cambridge University Press.

McGinnis, Michael D. 1986. "Issue Linkage and the Evolution of International Cooperation." Journal of Conflict Resolution 30(1): 141-170.

Meunier, Sophie. 2005. Trading Voices: The European Union in International Commercial Negotiations. Princeton: Princeton University Press.

Milner, Helen V, and Benjamin Judkins. 2004. "Partisanship, trade policy, and globalization: Is there a left-right divide on trade policy?" International Studies Quarterly 48(1): 95-119.

Patz, Ronny. 2016. "Just the TTIP of the Iceberg? Dynamics and Effects of Information Leaks in EU Politics." European Journal of Risk Regulation 7(2): 242-246.

Patz, Ronny. 2017. "Leaking, leak prevention, and decoupling in public administrations: the case of the European Commission." West European Politics 0(0): 1-23.

Pelc, Krzysztof J. 2017. "What Explains the Low Success Rate of Investor-State Disputes?" International Organization 71(3): 559-583. 
Pouliot, Vincent. 2010. International security in practice: the politics of NATO-Russia diplomacy. Vol. 113 Cambridge University Press.

Pozen, David E. 2013. "The Leaky Leviathan: Why the Government Condemns and Condones Unlawful Disclosures of Information." Harvard Law Review 127: 512.

Putnam, Robert D. 1988. "Diplomacy and domestic politics: the logic of two-level games." International Organization 42(3): 427-460.

Reich, Zvi, and Aviv Barnoy. 2016. "The Anatomy of Leaking in the Age of Megaleaks." Digital Journalism 4(7): 886-898.

Sagar, Rahul. 2013. "Creaky Leviathan: A Comment on David Pozen's Leaky Leviathan." Harvard Law Review 127: 75.

Starkey, Brigid, Mark A. Boyer, and Jonathan Wilkenfeld. 2005. Negotiating a Complex World: An Introduction to International Negotiation. 2 ed. Lanham: Rowman \& Littlefield Publishers.

Stasavage, David. 2004. "Open-Door or Closed-Door? Transparency in Domestic and International Bargaining." International Organization 58: 667-703.

Steinberg, Richard H. 2002. "In the Shadow of Law or Power? Consensus-based Bargaining and Outcomes in the GATT/WTO." International Organization 56: 339-374.

Sunstein, Cass. 1997. Free Markets and Social Justice. New York: Oxford University Press.

Woolcock, Stephen. 2016. European Union Economic Diplomacy: The Role of the EU in External Economic Relations. Milton Park: Routledge. 